\title{
Synthesis and Characterization of Carbapenem Based Nanohybrids as Antimicrobial Agents for Multidrug Resistant Bacteria
}

\author{
LETITIA DOINA DUCEAC ${ }^{1,4}$, GETA MITREA ${ }^{2,5 *}$, ELENA ARIELA BANU2,6*, MADALINA IRINA CIUHODARU $3,7 *$, \\ IRINA MIHAELA CIOMAGA ${ }^{3,4}$, DANIELA LUMINITA ICHIM ${ }^{2,8}$, MARCU CONSTANTIN ${ }^{2,9}$, ALINA COSTINA LUCA ${ }^{3,4}$ \\ ${ }^{1}$ Apollonia University of Iasi, Faculty of Medicine, Academician Ioan Haulica Institute of Researches, 2 Muzicii Str., 700399, Iasi, \\ Romania \\ 2University Dunarea de J os Faculty of Medicine and Pharmacy, 47 Domneasca Str., 800008, Galati, Romania \\ ${ }^{3}$ Grigore T. Popa University of Medicine and Pharmacy, Faculty of Medicine, 16 Universitatii Str., 700115, Iasi, Romania \\ ${ }^{4}$ Sf. Maria Clinical Emergency Hospital for Children, 62 Vasile Lupu Str., 700309, Iasi, Romania \\ ${ }^{5}$ Sf. Andrei Emergency Clinical Hospital, 177 Brailei Str., 800578, Galati, Romania \\ ${ }^{6}$ Sf. Ioan, Emergency Clinical Hospital, 2 Gheorghe Asachi Str., 800494, Galati, Romania \\ ${ }^{7}$ Elena Doamna Obstetrics and Gynecology Hospital, 29 Elena Doamna Str., 700398, Iasi, Romania \\ ${ }^{8}$ Dr. Iacob Czihac Military Emergency Clinical Hospital, 9 Henri Berthelot, 700483, Iasi, Romania \\ ${ }^{9}$ Saarbrucken- Caritasklink St. Theresia University Hospital, 2, D-66113 Saarbrucken, Germany
}

\begin{abstract}
Carbapenem antibiotics resistance is a medical threat in antibacterial therapy as the pathogen resistant strains easily evolve a multi-drug resistance action to other incurable agents. The protective transport of current antibiotic molecules using nano-carriers initiates a huge approach in the antibacterial therapy, allowing the nanohybrids to defeat all these health threat pathogen agents. Chitosan is a linear cationic polysaccharide being often used in medical area as a biocompatible encapsulating agent in antibiotic delivery nanosystems. This work refers to encapsulation of imipenem into biodegradable chitosan nanoparticles in order to destroy antibiotic-resistant bacteria and limit the microbial adhesion and multiplication. Nanoparticles were prepared by ion gelation method using tripolyphosphate as cross linking agent. The obtained hybrid nanocapsules were then characterized and evaluated as a potential nanodevice to beat antimicrobial resistance.
\end{abstract}

Keywords: nanohybrids, carbapenem, infection, multi-drug resistant germs, newborn, fetus, mother, infant, epidemiology.

Antibiotics had a major contribution along history of medicine by ensuring safe chemotherapy, surgical procedures and organ transplants. As the infectious diseases were considered the principal cause of death, both mortality and morbidity rates significantly decreased due to antibiotics.

Antimicrobial resistance is the ability of a microorganism to limit an antimicrobial from acting against it. As a consequence, standard treatments have no results and the infections persist spreading to other people.

The term multidrug-resistant bacteria refer to bacteria resistance to at least one antimicrobial agent. Antibioticresistant microorganisms are a huge public health problem in developing countries as well as in developed ones. Multidrug-resistant bacteria cause the difficulty of treatment, high costs and more adverse effects [1-6].

Critical pathogens include carbapenem-resistant pathogens i.e., Pseudomonas aeruginosa, Acinetobacter baumanii and all of the enterobacteriaceae that manifest resistance against carbapenem antibiotics. Nowadays the need of developing of new antibiotics against these three pathogen agents is one of highest priority.

The resistance in Gram $(+)$ bacteria is considere to be under control now butagainst Gram(-) has aggravated and represent a threat to public health.

Gram(-) bacilli include P.aeruginosa, A. Baumanii, E.coli, Klebsiella species, Salmonella and Enterobacter species that spread easily by hand carriage in addition to contaminated food and water.

Last decades it was observed the spread of enterobacteriaceae resistant to broad spectrum antibiotics and the occurrence of carbapenem-resistant entero- bacteriaceae have prescribed almost all the disposable therapies. Klebsiella pneumoniae is the recently discovered to make ineffective carbapenem. Enterobacteriaceae has evolved resistance against carbapenem which is considered to be the antibiotic of the lastresort, also due to the rate of prevalence of resistance [7-13].

Carbapenem antibiotics, e.g. meropenem and imipenem, (fig. 1), are novel broad spectrum $\beta$-lactam antibacterials with strong activity against serious infections. These drugs inhibit bacterial wall synthesis similar to other beta-lactams but carbapenems are highly resistant to degradation by $\beta$-lactamases and cephalosporinases. Carbapenems-resistant strains were recently found to be associated with resistance to a wide diversity of antimicrobial agents such as quinolones, aminoglicosides and cephalosporins.

Various approaches were investigated to deliver carbapenems molecular entity trying to realize the protection of carbapenem molecule from bacterial enzyme degradation and also to target carbapenem to the site of action. In order to accomplish these purposes, nano-sized carriers require drug chemical protection and appropriate targeting effect for efficient delivery of antibiotic molecules [14-20].

Polymeric nanoparticles are considered promising drugs delivery vehicle due to the suitable thermodynamic stability of the prepared drug containing nanohybrids. In addition to their ability to limit bacterial growth is the power to combat the expanding of multi-drug resistance providing more stability for loaded antibiotics against biodegradation, enhancing the circulation time inside the body and

*email: getamitrea@yahoo.com, banuariela@yahoo.com, mciuhodaru@yahoo.com 


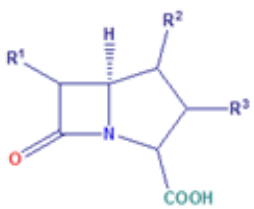

Backbone structure of a carbapenem

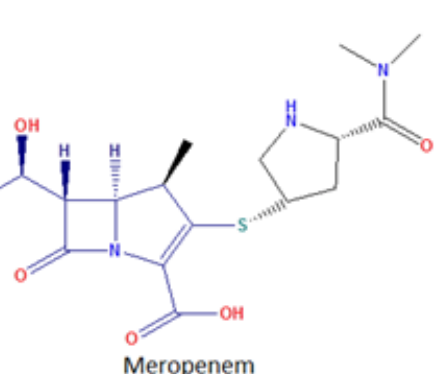

Meropenem
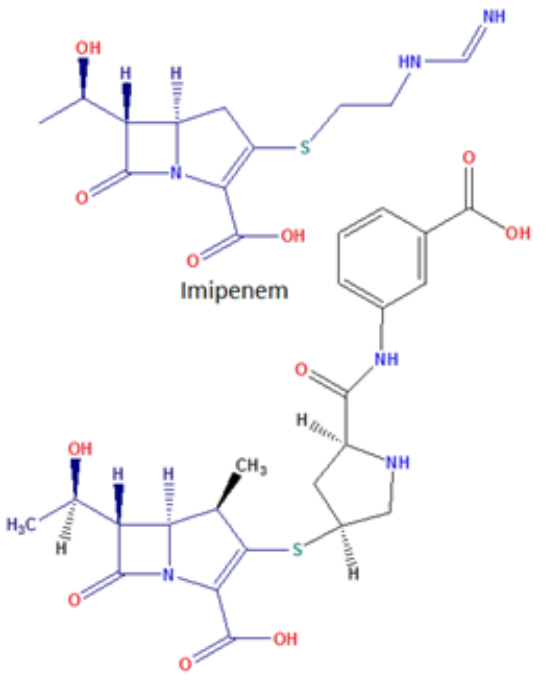

Ertapenem
Fig. 1. Chemical structure of carbapenem antibiotics

decreasing administration frequency and therapeutic dose. Polymer nanoparticles also augument localization of the loaded antibiotics to the infected site being associated with minimizing of the adverse effects of common administration [17-20].

Chitosan is a technologically important polysaccharide biopolymer, chemically consisting of two monosaccharides, $\mathrm{N}$ acetyl Dglucosamine and $\mathrm{D}$ glucosamine, linked together by $\beta(1 \rightarrow 4)$ glycosidic bonds (presented in fig. 2). The relative amount of the two monosaccharides in chitosan may vary, giving samples of different molecular weights $(50-2,000 \mathrm{kDa})$, degrees of deacetylation (75$95 \%)$, viscosities, pKa values, etc. Therefore, the term chitosan merely refers to a family of copolymers with various fractions of acetylated units [21-27]. Chitosan exhibits friendly characteristics meaning low toxicity, biocompatibility, biodegradability and, very important, antimicrobial activity which is due to its policationic nature that allows interactions with the negatively charged bacterial cell walls and cytoplasmatic membranes. All these features leads to osmotic instability, membrane breaking and leakage of intracellular contents 24-30].

In thıs work, imipenem loaded-chitosan nanoparticles were prepared and characterized in order to use them as nanohybrid antimicrobial agents for multidrug resistant bacteria.

\section{Experimental part}

Materials and methods

Imipenem loaded nanocapsules were obtained using ionic gelation method with minor improvements. Chitosan was dissolved in $1 \%$ acetic acid solution to an adjusted $\mathrm{pH}$ of 5.5 using a $6 \mathrm{M} \mathrm{NaOH}$ solution subjected to sonication for $30 \mathrm{~min}$. Tripolyphosphate (TPP) was dissolved in distilled water to an adjusted $\mathrm{pH}$ of $5.5 \mathrm{using} 0.5 \mathrm{M} \mathrm{HCl}$, and then both solutions were filtered using a $0.22 \mu \mathrm{L}$ syringe filter before use. Antibiotic was incorporated into an aqueous solution containing TPP and over mixing different volumes of chitosan and imipenem-containing TPP solutions, nanoparticles were spontaneously formed at varied chitosan-TPP weight ratios of 9:1; 8:1; 7:1; 6:1; 5:1; $4: 1 ;$ and $3 ; 1$.

\section{Results and discussions}

Zetasizer Nano ZS instrument was used for measure mean particle size and polydispersity index (PDI) before

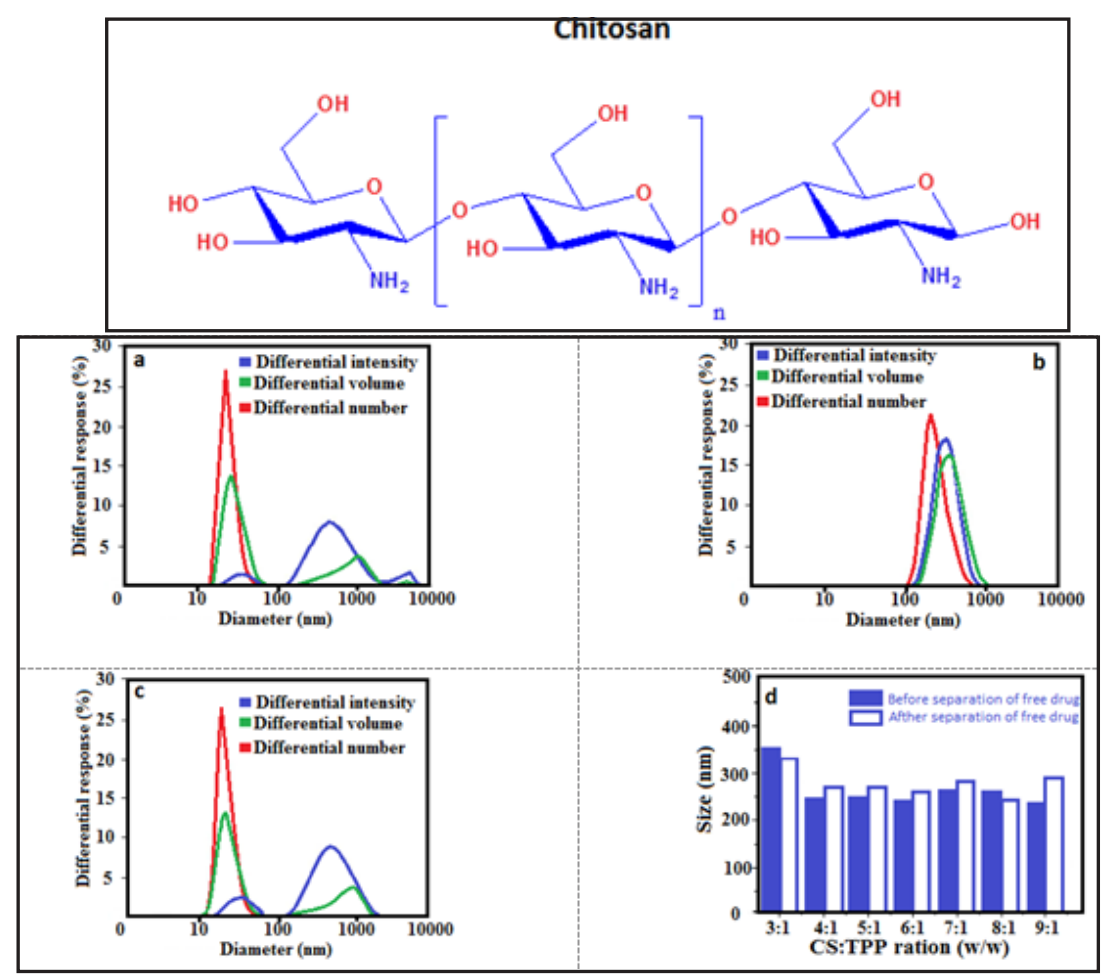

MATERIALE PLASTICE $\bullet 56$ No. $2 \bullet 2019$ http://www.revmaterialeplastice.ro
Fig. 2. Chemical structure of chitosan

Fig. 3. Intensity-, volume- and number-averaged hydrodynamic diameter histograms of imipenem-loaded nanoparticles prepared at chitosan:TPP weight ratio of 3:1 (a), 5:1 (b) and 9:1 (c). The effect of chitosan:TPP weight ratio

(9:1-3:1) on the size of imipenem-loaded nanoparticles before and after separation of the free antibiotic (d) 
and after separation of free imipenem. Laser Doppler anemometry was used for determination of zeta-potential values. High yields (70-75\%) of imipenem-loaded chitosan were obtained at different chitosan-TPP ratios. The average particle size diameter for imipenem-loaded nanoparticles ranged from 245 to $445 \mathrm{~nm}$ before separation and 245-375 after separation of free antibiotic (fig. 3a). Chitosan-TPP ratio played a significant role in the formation of nanoparticles and in setting their physicochemical features. Nanoparticles size decreased when increased the chitosan-TPP ratio from 3:1 to 4:1. From a chitosan-TPP ratio higher than $5: 1$, before and after separation of free drug, nanoparticles had PDI values larger than 0.5 due to the formation of aggregates. Analyses of number-, intensity- and volume- size distribution histograms (fig. 3bd) of the various formulations revealed the homogeneity of the nanoparticles prepared at chitosan-TPP ratio of 5:1, this formulation being selected for further analyses.

FTIR spectra of imipenem, chitosan, TPP, and imipenem loaded chitosan nanoparticles analysed chemical structure and complexes formation as shown in figure 4 . The main peaks corresponding to imipenem are at $3565 \mathrm{~cm}^{-1}$ for $\mathrm{OH}$ stretching vibration, $3402 \mathrm{~cm}^{-1}$ for $-\mathrm{NH}$ stretching, 3104 $\mathrm{cm}^{-1}, 2977 \mathrm{~cm}^{-1}, 2998 \mathrm{~cm}^{-1}$ for $-\mathrm{OH}$ stretching in $\mathrm{COOH}$, $1750 \mathrm{~cm}^{-1}$ for $\mathrm{COO}$ stretching in $\mathrm{COOH}$ group and $670 \mathrm{~cm}^{-}$ ${ }^{1}$ for $\mathrm{O}-\mathrm{H}$ bending in $\mathrm{COOH}$. Characteristic peaks of chitosan can be observed at $3370 \mathrm{~cm}^{-1}$ for $-\mathrm{OH}$ and $-\mathrm{NH}_{2}$ stretching, at $2870 \mathrm{~cm}^{-1}$ for $-\mathrm{CH}$ stretching vibrations, for $1653 \mathrm{~cm}^{-1}$ is attributed to $\mathrm{C}=\mathrm{O}$ stretching, $1595 \mathrm{~cm}^{-1}$ for $\mathrm{N}-\mathrm{H}$ bending, $1380 \mathrm{~cm}^{-1}$ for $-\mathrm{CH}_{3}$ symetrical deformation, for $1157 \mathrm{~cm}^{-1}$ for C-O-C anti-symetric stretching and C-N stretching, 1076 $\mathrm{cm}^{-1}$ is assigned to skeletal vibration of C-O stretching. For antibiotic-loaded chitosan nanoparticles, peaks of amide I and amide II of chitosan were shifted to $1640 \mathrm{~cm}^{-1}$ and $1560 \mathrm{~cm}^{-1}$ respectively and might be attributed to the electrostatic interactions between amino groups of chitosan and phosphoric groups of TP.

XRD pattern of chitosan, TPP, imipenem and imipenemloaded chitosan nanoparticles revealed the crystallinity of these compounds.

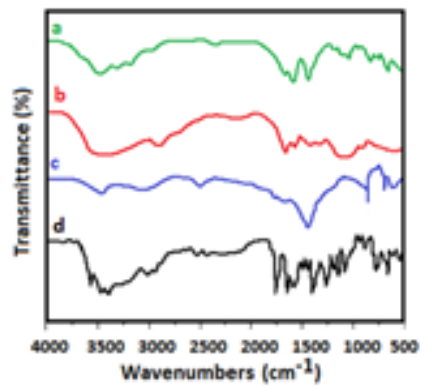

Fig. 4. FT-IR spectra of imipenem-loaded chotisan nanoparticles (CS:TPP weight ratio of $5: 1)(a)$, chitosan (b), $\operatorname{TPP}(c)$ and imipenem(d)

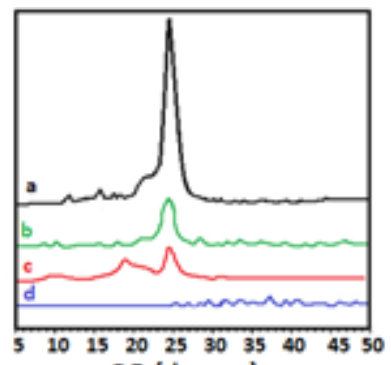

Fig. 5. X-ray diffraction patterns of imipenem (a), imipenem loaded Chitosan nanoparticles (CS:TPP weight ratio of 5:1) (b).chitosan (c), and TPP (d)

XRD patterns of imipenem, chitosan, TPP and imipenem-loaded chitosan nanoparticles are shown in figure 5. Imipenem presents multiple characteristic peaks due to its crystallinity. Three characteristic peaks in XRD pattern of chitosan were at $2 \theta$ of $10.20,19.56$ and 25.16 which may be assigned to the crystalline peaks associated with $-\mathrm{H}$ bond formation between $-\mathrm{OH}$ and $-\mathrm{NH}_{2}$ groups on chitosan chains.

Imipenem-loaded chitosan nanoparticles present a shift of peak position and modification of peaks intensities of chitosan and TP. The low intense peak at $2 \theta$ of 25.20 corresponds to crosslinking and characteristic peaks of imipenem disappeared possible due to the presence of antibiotic in a molecularly form encapsulated into the chitosan matrix.

\section{Conclusions}

Nanohybrids of narrow size distribution were successfully prepared by loading imipenem molecules into nanosized particles of chitosan at high encapsulation efficiency. The antibiotic-loaded nanoparticles were freezedried and resuspended in water maintaining their physicochemical properties thus being stored in a powdered form for pharmaceutical uses.

Intense antibacterial activity of drug-loaded nanoparticles was observed against multidrug-resistant pathogens, compared with free antibiotic molecules since nanoparticles increased and prolonged the bactericidal activity of the two antibiotics.

Therefore, imipenem-loaded chitosan nanoparticles could have great potential for control of bacterial infections and antimicrobial resistance besides the possibility of diminishing the dose and frequency of administration thereby improving patient compliance.

\section{References}

1. FABBRETTI, A., GUALERZI, C.O., BRANDI, L., FEBS Lett., 585, 2011, p. 1673-1681.

2. PIDDOCK, L.J., Lancet Infect Dis., 12, 2012, p. 249.

3. ALANIS, A.J., Arch Med Res, 36, 2005, p. 697.

4. AL-ASSIL, B., MAHFOUD, M., HAMZEH, A.R., Am J Infect Control, 41, 2013, p. 597.

5. CRETEANU, A., OCHIUZ, L., VASILE, C., VIERIU, M., TANTARU, G., Farmacia, 65, no. 4, 2017, p. 545.

6.CALIN, A.M., DEBITA, M., DRAGOMIR, R., STEFANESCU, O.M., BUDACU, C., SZALONTAY, A.S., Rev Chim (Bucharest), 68, no. 11, 2017, p. 2618.

7. PICKERING, L.K., In Seminars in pediatric infectious diseases, WB Saunders, 15, 2004, p. 71.

8. PATERSON, D.L., Am J Med, 119, 2006, p. S20.

9. LUPO, A., Papp-Wallace, K.M., Sendi, P., Bonomo, R.A., Endimiani, A., Diagn Microbiol Infect Dis, 77, 2013, p. 179.

10. TALUKDAR, P.K., RAHMAN, M., RAHMAN, M., NABI, A., ISLAM, Z., HOQUE, M.M., ENDTZ, H.P., ISLAM, M.A., Plos One 8, 2013, e61090.

11. BOLOGA, C.G., URSU, O., OPREA, T.I., MELANCON, C.E., TEGOS, G.P., Curr Opin Pharmacol, 13, 2013, p.678.

12. JAMIL, B., IntJ Innov Appl Stud, 9, 2014, p. 1736.

13. WELLINGTON, E.M., BOXALL, A.B., CROSS, P., FEIL, E.J., GAZE, W.H., HAWKEY, P.M., J OHNSON-ROLLINGS, A.S., JONES, D.L., LEE, N.M., OTTEN, W., THOMAS, C.M., Lancet Infect Dis, 13, 2013, p. 155. 14. KOHLER, T., MICHEA-HAMZEHPOUR, M., EPP, S.F., PECHERE, J.C., Antimicrob Agents Chemother. 43, 1999, p. 424.

15. QUALE, J., BRATU, S., GUPTA, J., LANDMAN, D., Antimicrob Agents Chemother. 50, 2006, p. 1633.

16. MELETIS, G., EXINDARI, M., VAVATSI, N., SOFIANOU, D., DIZA, E., Hippokratia. 16, 2012, p. 303.

17. VENTOLA, C.L., Pharm Ther. 40, 2015, p. 277.

18. CRETEANU, A., OCHIUZ, L., VIERIU, M., TANTARU, G., MedicalSurgical Journal (Revista Medico-Chirurgicala), 122, no. 4, 2018, p. 840.

19. NOVAC, O., BARBACARIU, L., SLANINA, A.M., FRASINARIU, O.E., TRANDAFIR, L.M., Medical-Surgical J ournal (Revista MedicoChirurgicala), 122, no. 4, 2018, p. 689 
20.BROOKS, B.D., BROOKS, A.E., Adv Drug Deliv Rev., 78, 2014, p. 14. 21.CHEOW, W.S., HADINOTO, K., Methods Mol Biol., 1147, 2014, p. 227.

22.SAMIEI, M., FARJAMI, A., DIZAI , S.M., LOTFIPOUR, F., Mater Sci Eng C Mater Biol Appl., 58, 2016, p. 1269.

23.HOFMANN, D., MESSERSCHMIDT, C., BANNWARTH, M.B., LANDFESTER, K., MAILANDER, V., Chem Commun (Camb)., 50, 2014, p. 1369.

24.TUROS, E., SHIM, J.Y., WANG, Y., GREENHALGH, K., REDDY, G.S., DICKEY, S., LIM, D.V., Bioorg Med Chem Lett., 17, 2007, p. 53.

25. ILLUM, L.,. Pharm. Res., 15, 1998, p. 1326.
26. SINGLA, A. K., CHAWLA, M., J. Pharm. Pharmacol., 53, 2001, p. 1047.

27. HARANATHAN, R. N., KITTUR, F. S., Crit. Rev. Food Sci. Nutr. 43, 2003, p. 61.

28. BLECHER, K., NASIR, A., FRIEDMAN, A. Virulence, 2, no. 5, 2011, p. 395.

29.BANERJEE, M., MALLICK, S., PAUL, A., CHATTOPADHYAY, A., GHOSH, S. S., Langmuir, 26, no. 8, 2010, p. 5901.

30. MA, Y., ZHOU, T., ZHAO, C., Carbohydrate Research, 343, 2, 2008, p. 230.

31. SANPUI, P., MURUGADOSS, A., PRASAD, P. V., GHOSH, S. S., CHATTOPADHYAY, A., International J ournal of Food Microbiology, 124, 2, 2008, p. 142.

Manuscript received: 14.02 .2019 